\title{
Selskabet for Udgivelsen af danske Folkeskrifter
}

\author{
Af Olab Christensen.
}

I 1835 var Selskabet for Trykkefrihedens rette Brug, som havde til formål at virke for udbredelse af god folkelæsning og at ophjælpe lokale blade, blevet stiftet i København. Det fik først betydning for Sønderjylland, efter at Orla Lehmann den 4. november 1836 havde holdt en tale, hvori han opfordrede til, at selskabet skulle udvide arbejdet til også at omfatte denne landsdel for „at fremkalde en større åndelig tilnærmelse mellem de to dele af det danske folk". Talen havde god virkning i kongeriget, men $i$ Sønderjylland gik det trægt, her var selskabets medlemstal, da det i 1839-40 nåede sit højdepunkt, kun på godt 200, hvoraf 44 i Haderslev og omegn og 38 i Tørninglen.

Selskabets skrifter *egnede sig ikke til begyndende folkelæsning, for åndelige småkårsfolk var dets tidsskrift bundkedeligt, og dets udvalg af bøger sommetider uheldigt ", skriver P. Lauridsen, ${ }^{1}$ og da bøgerne $\mathrm{i}$ de første år uddeltes tilfældigt, vakte selskabets virke ikke udelt tilfredshed.

\Dannevirke «s redaktør, Peter Christian Koch, var blandt selskabets kritikere. Han tog til orde imod det $i$ et brev til professor Flor og foreslog i stedet oprettet små lånebiblioteker. Da Flor tiltrådte denne tanke, blev resultatet, at der stiftedes en række lejebiblioteker, bl. a. Kocks eget, og det gav stødet til dannelsen af Selskabet for dansk Læsnings Udbredelse i Slesvig, som oprettede 62 biblioteker med i alt $20-25.000$ bind, hvoraf over halvdelen i Haderslev amt. ${ }^{2}$ Selskabets virke ophørte med Treårskrigen, men da havde bibliotekerne gjort den danske bog kendt i Sønderjylland og havde lagt grunden til det oplysningsarbejde, som tog sin begyndelse efter krigens afslutning. 
Slesvig-holstenernes nederlag medførte store omvæltninger i Sønderjylland. Det kom bl. a. til udtryk ved, at en lang række slesvig-holstenske embedsmænd blev udskiftet med dansksindede. Til Haderslev by og egn kom der foruden en del jurister en lang række præster og lærere.

Mange af de nye embedsmænd tog straks ivrig del i det kulturelle liv og blev en kærkommen styrkelse af de danske kredse. I Haderslev sluttede de sig til Selskabet Harmonien, som var blevet stiftet i 1849. Her holdt de foredrag og festtalerne ved de nationale fester, ${ }^{3}$ men også på andre områder blev de aktive $i$ arbejdet for dansk kulturs fremme $i$ det forsømte grænseland.

Blandt de nye embedsmænd møder vi præsterne J. V. Marckmann og F. E. Boisen samt de to skolemænd, rektor S. B. Thrige og konrektor Edvard Lembcke.

Jørgen Vilhelm Marckmann var født i Rønne i 1804 og havde været præst i København, da han i oktober 1850 blev sognepræst i Hoptrup. Han var stærkt grebet af tidens folkelige og nationale vækkelse og havde været medlem såvel af den grundlovgivende rigsforsamling som af folketinget.

Frederik Engelhardt Boisen var født i Vesterborg i 1808 og havde bl. a. været præst i Skørpinge, der lå i den vakte del af Sjælland. Boisen havde her sluttet sig til forsamlingsfolkene, og hans præstegård havde været samlingssted for de vakte, men efter et besøg hos Grundtvig i 1845 havde han fået øjnene op for skævhederne ved forsamlingslivet. Han havde som Marckmann været medlem af den grundlovgivende rigsforsamling og var medlem af folketinget, men da han i oktober 1850 blev kaldet til sognepræst i Vilstrup, nedlagde han i 1851 sit mandat.

Søren Bloch Thrige var født i Roskilde i 1820 og havde studeret filologi og historie. Han var lærer ved Roskilde Katedralskole, da han i 1850 blev udnævnt til rektor ved Haderslev lærde skole.

Edvard Lembcke var født $i$ København i 1815 som søn af en indvandret prøjser, havde studeret teologi og var adjunkt i Odense, da han i 1850 blev udnævnt til konrektor i Haderslev. Han gjorde senere sit navn kendt som oversætter, hvor hans hovedværk er Shakespeare, men er bedst kendt for sine sønderjyske digte, hvoraf de bedste blev skrevet i Haderslev og sunget første gang her. 
Marckmann og Boisen må som medlemmer af rigsforsamlingen og folketinget have mødt hinanden, før de kom til Sønderjylland, men de to andre har de sandsynligvis kun kendt af navn, hvis de har haft kendskab til dem, ligesom Thrige og Lembcke næppe har truffet hinanden personligt, før de under rejsen til Haderslev mødtes i Odense. ${ }^{4}$

Der udviklede sig hurtigt et venskabsforhold mellem de fire familier. Marckmanns datter, Judithe, der blev gift med Haderslev-advokaten Carl Salicath, skriver i sine erindringer, ${ }^{5}$ at Lembcke var faderens "uendelig gode ven“, og at familien i Hoptrup havde megen omgang med Boisens i vilstrup. Lembcke fortæller, ${ }^{6}$ at han havde et venskabeligt forhold til familien Thrige og familien Boisen, medens venskabsforholdet til Marckmanns har været mere intimt.

Blandt Haderslev bys personligheder mader vi "Dannevirke"s redaktør, Peter Christian Koch, som må have været kendt af de fleste af de nye embedsmænd. Da Lembcke efter sin ankomst til byen ønskede at sætte sig nærmere ind i de slesvigske forhold, opsøgte han i alt fald Koch, som blev den, der førte de fleste af de nye mænd ind i "Harmonien “. ${ }^{7}$ De fire blev optaget ret omgående, Thrige og Lembcke i $1850 \mathrm{og}$ de to præster $\mathrm{i}$ begyndelsen af 1851.8

P. Chr. Koch var af den opfattelse, at et bogtrykkeri skulle virke til oplysningens fremme, men mente, at dette mere „beroede på dygtige og flittige forfattere end på dets nye typer og flinke maskinværk“, og at „der overhovedet ikke kunne gøres sådanne fordringer til et provinstrykkeri som til et officin i hovedstaden, hvor de vigtigste forfatterpenne er samlede, og hvorhen de vigtige manuskripter elektrisk drages, selv om de kunne ekspederes nok så fuldkommen i provinstrykkeriet “. ${ }^{9}$

Koch var godt tilfreds med det af ham selv drevne trykkeri, som var oprettet af svenskeren Hinrich Luckander i 1759, og som efter at have tilhørt Jens og Heinrich Seneberg i 1848 var overtaget af ham. Herfra var der lige fra starten udgået en lang række folkelige og opbyggelige skrifter, ${ }^{10}$ og selv om Koch omtalte småskrifterne "som vidne om dannnelsens allerlaveste trin“, føjede han dog til, at trykkeriet „skønt det forst nu er sig sit formål klart bevidst, så har det under de tre foregående lederes hænder dog 
trolig tjent den danske sag ved stadig at udsende folkelæsning $i$ det danske sprog“. Det havde kun i en halv snes år før Treårskrigen virket for slesvig-holstenernes sag, men i ovrigt „været en stille kilde, der stadig vandede de fra de danske litteraturstrømme afskårne egne med folkeviser, gudelige og morsomme skrifter, skolebøger etc. $i$ det danske sprog, og bevarede således en nødlitteratur til bedre tider“, ligesom „det var kendeligt i de danske egne af Slesvig, f. eks. omkring Flensborg og Tonder, at et bogtrykkeri af lignende art der har manglet." $\theta$

Det er rigtigt, at den største del af de folkebøger og viser, som var udgået fra trykkeriet i Haderslev, kun var af ringe værd, men til gengæld strømmede de ud derfra i store mængder, selv om det skete mere af merkantile end af nationale og folkelige grunde. Småskrifterne har for den del af folket, som var henvist til meget let tilgængelig litteratur, dækket et vist læsebehov og har derfor haft deres store betydning, idet de ofte var hovedparten af den litteratur, måske den eneste, vi ville møde i småkårshjem.

Småskrifterne må heller ikke alle underkendes, vi finder blandt dem nogle af de ældste udgaver af molbohistorierne, ${ }^{11}$ og folkemindeforskeren Axel Olrik fremhæver, ${ }^{12}$ at bogtrykkeriet i Haderslev $i$ en tid, da de københavnske trykkerier trykte arier og drikkeviser, sendte en mængde af de bedste gamle folkeviser ud til bondehjemmene nær og fjern.

Der var altså god tradition for udsendelsen af folkelæsning fra Haderslev, og der kan derfor ikke herske tvivl om, at redaktør Koch har hilst mulighederne for en udbygning af trykkeriets medvirkning i folkeoplysningen med den største glæde. Allerede i 1851 må en sådan mulighed være drøftet mellem ham og de nye embedsmænd, hvoraf flere straks var blevet flittige og dygtige medarbejdere ved „Dannevirke“. Det første samarbejde blev etableret med pastor Boisen, som fra 1. januar 1852 med Koch som trykker og forlægger udgav „Budstikken, et folkeskrift til oplysning og opbyggelse". Det vandt hurtigt god udbredelse og fandt endog vej op til Norge. ${ }^{13}$

I 1851 må tanken om udsendelsen af folkeskrifter være ventileret af pastor Marckmann, der havde været et virksomt medlem af Trykkefrihedsselskabet, for hvilket han havde udgivet „Fortegnelse over skrifter til læsning for menigmand“.14 Tanken må 
have fået tilslutning fra pastor Boisen og de to skolemænd, og $\mathrm{i}$ løbet af vinteren 1851-52 har de fire fảet tilsagn fra andre om at være med som indbydere ved dannelsen af et selskab, og den 23. marts 1852 blev følgende avertissement indrykket $i$ "Dannevirke :

"De Herrer, som have tegnet sig som Indbydere til at danne et Selskab til Udgivelse af danske Folkeskrifter, opfordres herved til at møde $\mathbf{i}$ »Harmonien"s Lokale Mandagen den 29. Marts, Kl. 3.

Marckmann F. E. Boisen Thrige E. Lembcke."

Selskabet må derefter være oprettet den 29. marts, idet de fire indbydere, der formentlig samtidig er blevet valgt til den første bestyrelse, $i$ juli måned anmodede en række blade ${ }^{15}$ om at optage en bekendtgørelse om, at de udsendte planer snarest måtte tilbagesendes. Det fremgår heraf, at der havde været fremlagt tegningslister i København, hvor de skulle indsendes til Den Gyldendalske Boghandel, andre havde været fordelt gennem præster og lærere, til hvem de atter skulle indsendes, og endelig var der andre, som var udsendt på anden måde og nu skulle tilbagesendes direkte til et af bestyrelsens medlemmer.

Medlemstegningen har været tilfredsstillende eller $\mathrm{i}$ alt fald så stor, at indbyderne turde lade selskabet træde ud i livet, og det blev derfor bestemt, at det skulle begynde sin virksomhed den 1. oktober $1852 .{ }^{16}$

Selskabets formål var at bidrage til menigmands oplysning ved at udgive folkeskrifter af belærende såvel som af underholdende indhold. ${ }^{16}$ Selv om det kom til at omfatte hele landet, har stifterne vel i første række tænkt sig, at det skulle styrke og udbrede dansk kultur i grænselandet. Det bekræftes af $\gg$ Dannevirke $",{ }^{17}$ som i en omtale af selskabets første lille bog skrev, at dets „øjemed var vel nærmest stadig at lade trykke nyttige og underholdende danske bøger for folket i Slesvig; men da de samme bøger tillige ville være nyttige og underholdende for hver dansk, og da man behøvede medlemmer, ligemeget hvor de boede i fædrelandet, så er der ingen grænse bleven sat med hensyn til selskabets virksomhed $\mathbf{i}$ nogen del af riget."

For at blive medlem kunne man abonnere på skrifterne på et postkontor i kongeriget eller i Slesvig eller rette henvendelse til bestyrelsens medlemmer. Medlemskontingentet udgjorde 2 mark 
(10 sk. kurant) kvartalet eller frit tilsendt med posten 2 mark $6^{1 / 2}$ sk. (12 sk. kurant). ${ }^{18}$

Som den første bog valgte selskabet at udsende en skildring af Treårskrigen, forfattet af historikeren Fr. Hammerich. Han havde deltaget i krigen som feltpræst, havde derfor været begivenhederne inde på livet og havde gennem skildringer af enkelte felttog "vakt publikums længsel efter mere af samme slags“. Hammerich var straks villig til at påtage sig arbejdet og gjorde i løbet af sommeren 1852 bogen færdig. Den forelå færdigtrykt hos P. Chr. Koch henimod jul 1852 »i flere tusinde eksemplarer", skrev „Dannevirke“. ${ }^{17}$

$V i$ vil vare tilbøjelige til at tro, at bladet overdrev, men det var ikke helt galt. Bogen må være trykt i op mod 3000 eksemplarer. Ifølge selskabets forste regnskab ${ }^{19}$ var der i Haderslev og omegn 111 medlemmer, medens postvæsenet havde opkrævet kontingent hos 883 medlemmer, og desuden var der 57 medlemmer i Nakskov og Køge. Det giver $i$ alt 1051 medlemmer, når hertil lægges ca. 90 gennem boghandelen solgte eksemplarer og den resterende beholdning 1556, giver det et oplag på omtrent 2700 .

Selskabets bestyrelse synes at have været optimister, men den har vel regnet ud fra Trykkefrihedsselskabets tal ${ }^{20}$ og ikke fra det forud tegnede antal medlemmer. Det må derfor være blevet en skuffelse for den, at medlemstallet kun blev på godt 1000, men har dette været en skuffelse, har de følgende år budt på endnu større. Efter de foreliggende regnskaber kan medlemstallet ved regnskabsårets udgang pr. 1. oktober opgores således:

1853 til 935 heraf 114 i Haderslev by og omegn, ${ }^{19}$ 1854 til 751 heraf 132 i Haderslev by og omegn, ${ }^{21}$ 1858 til 571 heraf 105 i Haderslev by og omegn ${ }^{22}$ og 1860 til 526 heraf 101 i Haderslev by og omegn, ${ }^{23}$ medens det i 1861 igen var vokset til op $\bmod 600 .^{24}$

Oplagstal opgives ikke, men enkelte skrifter er ikke udgivet af selskabet, men købt hos et forlag og derefter tilsendt medlemmerne iklædt skrifternes særprægede omslag. Antallet af købte eksemplarer viser tydeligt, at medlemstallet var faldende, og bekræfter de foran beregnede tal. Af de bevarede regnskaber ${ }^{25}$ kan det ses, at man af 5 . bind har købt 900 af boghandler Thaarup i København, af 17. og 26 . bind 700 og af 29 . og 32 . bind 600 af Iver- 


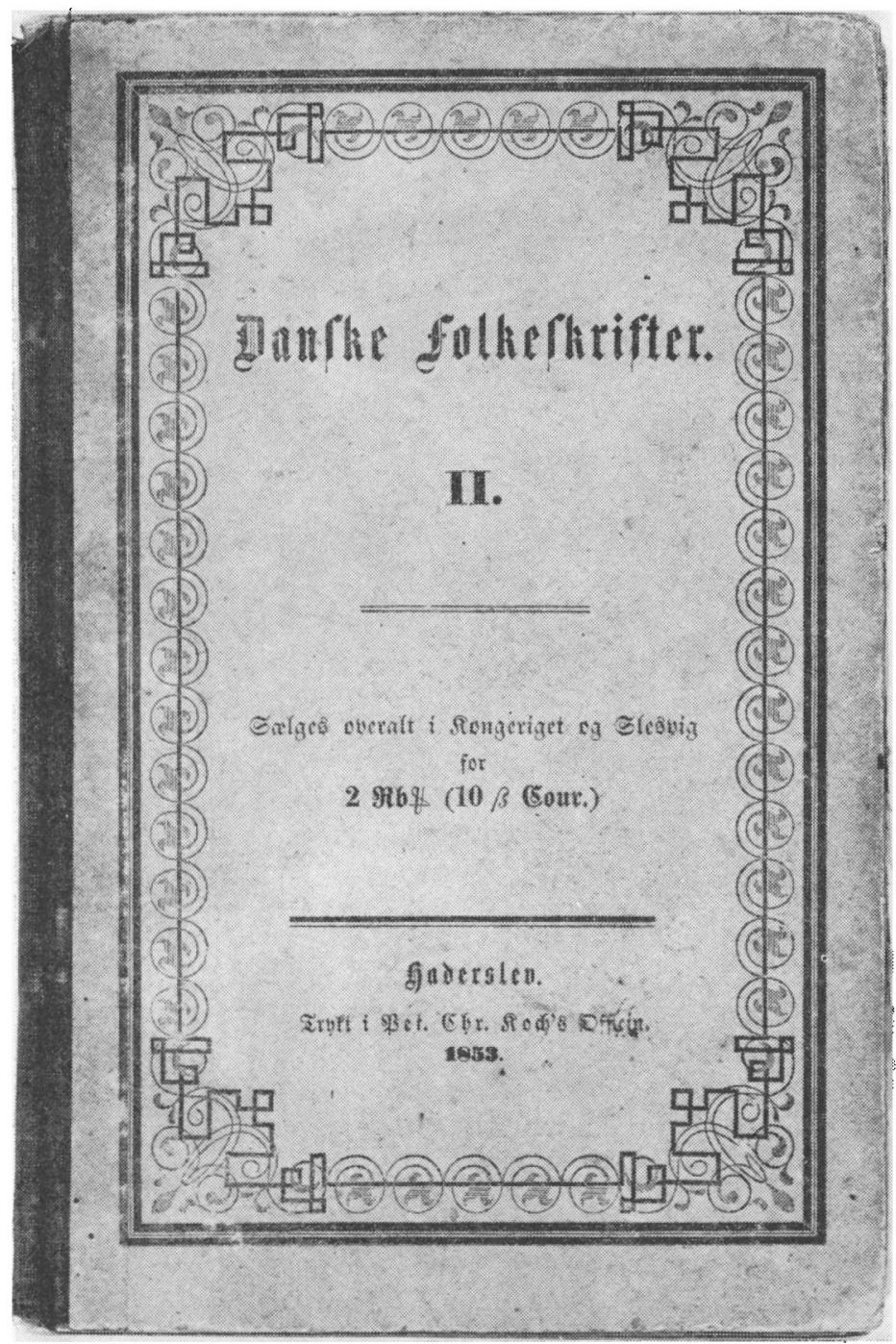

Folkeskrifternes omslag $i$ de forste år. Senere blev rammen mere enkel og bestod kun af to streger.

sens forlag, af 28. og 30 . bind 550 af henholdsvis redaktør Godske Nielsen og af det norske Selskab for Oplysningens Fremme og endelig af bind 31 af redaktør Godske Nielsen 516, som må svare til medlemstallet i 1860. 
Bestyrelsens bekymringer over det faldende medlemstal kom til udtryk straks $i$ det første regnskab. ${ }^{19}$ Til det stadig faldende antal postabonnenter, som i de første fire kvartaler var på henholdsvis 883, 867, 809 og 779, knyttedes følgende kommentar: „Det er desværre næsten uundgåeligt, at dette måtte indtræde ifølge den måde, hvorpå postkontorerne er nødsagede til at opkræve betalingen. Men da selskabets virksomhed naturligvis må vinde eller tabe i omfang i forhold til medlemmernes antal, tillader bestyrelsen sig at opfordre enhver, der måtte føle sig nogenlunde tilfredsstillet ved dets hidtilværende virksomhed, til at virke $\mathbf{i}$ sin kreds for at flere medlemmer tegne sig. Der er tilbudt selskabet flere værdifulde skrifter, og jo større medlemmernes antal bliver, desto flere sådanne ville de jo erholde uden at betale mere derfor."

Opfordringen havde ikke den ønskede virkning. Medlemstallet faldt stadig, og $i$ andet års regnskab ${ }^{21}$ kom bekymringerne atter til udtryk. Man fremhævede, at selskabet ikke ville kunne fortsætte sin virksomhed ret længe, såfremt medlemstallet stadig blev mindre. I 1856 søgte bestyrelsen at hverve medlemmer, og den mente, at selskabet fortjente støtte, men det, at det »har sit midtpunkt $i$ en slesvigsk by, må anbefale det til fædrelandssindede mænds særdeles opmærksomhed. Thi intetsteds trænger man mere til enhver virksomhed, som går ud på at fremme dansk oplysnings og vække sansen for dansk læsning hos menigmand og tilbyde den næring. Derfor vil man vel også finde det $i$ sin orden, at den første plads i rækken af de udgivne skrifter optages af sådanne, som udbreder kundskab til fædrelandets historie"..26

Set med nutidsøjne kan det vel siges, at selskabet udmærket kunne være sit medlemstal bekendt. Det var ikke billigt at være medlem, to mark i kvartalet var et ret stort beløb at ofre på læsning. Det gjorde det $i$ alt fald umuligt for den brede befolkning at være medlem, og medlemmerne skal sikkert søges $\mathrm{i}$ embedsmandskredse og hos mere velhavende borgere og bønder; men desværre ved vi intet herom.

Selskabet har hele tiden måttet kæmpe med ret store vanskeligheder. Det første års regnskab viste et underskud på 298 rdlr. 4 mark 12 sk., som udelukkende hidrørte fra 1 . hæfte, der havde kostet godt $650 \mathrm{rdlr}$., idet de ovrige hæfter omtrent havde hvilet i sig selv. Det andet år var underskuddet vokset til 528 rdlr. 
2 mark 7 sk. Det skyldtes først og fremmest de faldende indtægter, men også hæfte 6, som kostede godt 650 rdlr. Det følgende regnskab for tiden til 1. oktober 1856 savnes, men har kunnet afsluttes med en kassebeholdning på 124 rdlr. 1 mark 11 sk., hvilket overskud den 1 . oktober 1858 var blevet til et underskud på 236 rdlr. 1 mark 13 sk. ${ }^{27}$

I lobet af 1859 eller 1860 modtog selskabet en understøttelse på 200 rdlr. fra det kongelige ministerium for hertugdømmet Slesvig, men alligevel havde det den 1 . oktober 1860 et underskud på 113 rdir. 5 mark 13 sk., og selv om bestyrelsen trøstede sig selv og medlemmerne med, at der „til at opveje dette deficit haves dels temmelig betydelige udestående fordringer, dels restbeholdningen af adskillige skrifter", har okonomien formentlig stadig voldt en del bekymring. ${ }^{28}$

Selv om det ikke lykkedes at få medlemstallet sat i vejret, er virksomheden fortsat, og i løbet af 1862 steg abonnenternes antal „ikke ubetydeligt“, og antallet af købere i boghandelen var tiltagende, således at der var en kendelig fremgang. ${ }^{29}$ Selskabet har derefter med uforandret energi fortsat sin virksomhed til 1864 , og det har kunnet udsende 46 hæfter, d.v.s. et i 1852, gennemsnitlig fire i hvert af årene 1853 til 1863 og et i 1864 .

De fleste af skrifterne er antaget og udsendt af selskabet. De indsendte manuskripter cirkulerede blandt bestyrelsens medlemmer, og antagelse var betinget af, at den samlede bestyrelse kunne godkende manuskriptet. ${ }^{30}$ I 1840'erne havde Fr. Hammerich udgivet et par bidrag til Danmarks historie, som var startet med en skildring af "Danmark i Valdemarernes Tid“ og skyldtes en opfordring fra Trykkefrihedsselskabet. Den blev fortsat i »Danmark under Kongerne af den ældre oldenborgske Linie ", hvis sidste bind i 1854 overtoges og udsendtes af Folkeskriftselskabet, ${ }^{31}$ som også udgav fortsættelsen: ^Danmark under Adelsvælden «, der udkom i ti hæfter.

Enkelte hæfter er købt hos et forlag, ${ }^{32}$ det gælder som nævnt nr. 5 og Marckmanns bog om sprogforholdene (nr. 28 og 31), som mærkelig nok ikke var udgivet af det selskab, som Marckmann havde stiftet, men først købt, efter den var halvt færdig, samt nr. 23, som blev købt af Gyldendalske Boghandel, som ved brev af 9 . februar 1858 meddelte Thrige, at forlaget - så snart 
skibsfarten begyndte - ville sende 600 eksemplarer af Holberg: -Epistler ${ }^{3 .}{ }^{38}$ Forlaget ønskede dog oplyst, om der skulle trykkes et andet titelblad eller omslag for at betegne, at bogen kom fra Folkeskriftselskabet. Da der udover $300 \mathrm{rdlr}$. for selve bogen foruden fragt er betalt for indhæftning, ${ }^{34}$ kan vi sikkert gå ud fra, at det sædvanlige omslag er anvendt, men intet eksemplar kendes $\mathrm{i}$ denne indbinding. ${ }^{35}$ Endelig er $\mathrm{nr} .22$ og 30 overtaget fra Selskabet til Folkeoplysningens Fremme i Norge.

I dette selskabs møde den 11 . maj 1857 forelå der forslag om, at selskabet burde træde $i$ nærmere forbindelse med det danskslesvigske selskab, for at der kunne komme en bytteforbindelse i gang, og da pastor Boisen ved brev af 25 . juni meddelte, at Haderslev-selskabet var interesseret $i$ et samarbejde, blev det $i$ mødet den 7. september vedtaget, at de to bestyrelser skulle tilstille hinanden deres skrifter, og at skrifter, som egnede sig for begge lande, efter ønske skulle trykkes $i$ så stort et oplag, at de kunne overtages af det andet selskab og udsendes også til dettes medlemmer ${ }^{86}$ "Dannevirke hilste dette initiativ med stor tilfredshed, idet det anså ,ethvert sådant tilnærmende skridt imellem danske og norske i literair henseende for yderst gavnligt ${ }^{\alpha}{ }^{37}{ }^{37}$

Det første resultat af samarbejdet var, at man sendte hinanden de hidtil udgivne skrifter. Fra Haderslev sendtes - med undtagelse af nr. 5 og 7 - fra to til tyve eksemplarer af hvert, medens Haderslev-selskabet synes at have fảet overdraget et noget større antal, idet det til folkebibliotekerne skænkede et ikke ringe antal af de modtagne småbøger, som var af endnu mere populær karakter end de danske og »egne sig i høj grad til læsning af menigmand, som herved vil erholde ganske gode bidrag til det norske folks sæder og kår « ${ }^{38}$ Det norske selskab, der talte over 5000 medlemmer, synes også at have fordelt de danske skrifter til sogneselskaber og almuebiblioteker.

Ved brev af 7 . januar 1858 fremkom der fra Haderslev ønske om med enkelte småændringer at måtte udsende et nyt oplag af Hartvig Lassens afhandling i "Folkevennen " om krigen med Rusland, og da forfatteren intet havde at indvende herimod, udsendtes bogen samme år (nr. 22). I 1859 fremkom der fra dansk side ønske om at overtage 550 eksemplarer af Daas bog "Skandinaviens Beskrivelse " (nr. 30), men først i 1861 viste det norske sel- 
skab interesse for en af de danske publikationer, idet det bad om at få 5000 eksemplarer af » Krigen i Norditalien 1859 " (nr. 37), som ønskedes trykt i samme format som »Folkevennen". Der synes da at være opstået nogen mislyd, idet skriftet kom til at koste 442 speciedaler 85 sk., medens det i Norge ville kunne være trykt for 375 speciedaler. Senere afviste det norske selskab et tilbud om at overtage »Krigen i Syditalien 1860 ", og dermed synes forbindelsen mellem de to selskaber at være ebbet ud.

Pastor Boisen blev i 1859 præst i Stege, men først i 1860 blev lærer ved Haderslev lærde skole Carl Christian Grønlund, der allerede i 1853 var optrådt som forfatter $i$ et hæfte med blandinger (nr. 4) og i 1857 til et selvstændigt skrift (nr. 18) optaget i bestyrelsen, fra 1862 var han selskabets sekretær ${ }^{39}$ og kasserer og senere forfatter til hæfte nr. 36 og 44. Pastor Boisen synes at have været sjælen $i$ foretagendet, idet der ikke udkom noget skrift fra juli kvartal 1859 til juni 1860 , hvorfor "Dannevirke" håbede, at bestyrelsen ved denne supplering virkelig havde afhjulpet »en dybt følt trang ", så Grønlund virkelig måtte bringe nyt liv ind $i$ den. ${ }^{40}$

Chr. Grønlund, der var student fra Kolding, blev teologisk kandidat i 1850, men da det teologiske studium ikke havde tilfredsstillet ham, gik han lærervejen og var en tid lang huslærer hos pastor Marckmann, ${ }^{41}$ hvor hans interesse for naturfagene blev øget, og blev 1851 lærer ved Haderslev lærde skole med naturhistorie som hovedfag.

"Dannevirke" havde ikke noget at indvende imod det nye bestyrelsesmedlem, men havde fundet det mere rimeligt, at valget var blevet overladt selskabets lokale medlemmer, navnlig fordi selskabet kunne have gjort så overmåde megen nytte, men stadig gik tilbage, men også fordi lovene sikkert måtte påbyde en sådan fremgangsmåde. Bladet tilføjede, „måske eksisterer der stadig i kraft af gemytlighedens princip slet ingen love, og så er jo bestyrelsen i så henseende undskyldt " ${ }^{40}$ Hvorvidt der har eksisteret love, ved vi ikke, bevarede er de $i$ alt fald ikke.

Kun én gang til skete der ændringer i bestyrelsens sammensætning, nemlig i 1861, da selskabets stifter pastor Marckmann døde den 11. juli og blev erstattet med pastor Harald Valdemar Rasmussen, som fra 1851 havde været præst i Halk, og som havde 
bidraget til hæfte 35 med en artikel om Nis Lorentsen. Han optræder fra bind 38 som medlem af bestyrelsen, og i 1862 møder vi ham som forfatter til hæfte 41 .

Marckmann var forfatter til hæfterne 7, 21, 28 og 31, og det var tanken $\mathrm{i} 1861$ at udsende en skildring af ham af vennen C. F. Allen, ${ }^{42}$ men den kom ikke til udførelse. Boisen og Thrige har været forfattere til hver et hæfte, nr. 3 og 38. Konrektor Lembcke er det eneste af bestyrelsesmedlemmerne, som ikke optræder blandt skriftrækkens forfattere.

Selskabet har naturligvis også støttet dansk bogarbejde i Slesvig, det har foruden de omtalte norske småskrifter i 1860 overladt Komiteen til Oprettelse af Folkebiblioteker i Slesvig 564 hæfter til uddeling. ${ }^{43}$

Skrifterne udsendtes i hovedkommission hos boghandler Theodor August Møller, ${ }^{44}$ som den 9. juni 1842 var blevet borger i Haderslev, hvor han havde overtaget byens ældste boghandel, der havde eksisteret siden 1765.45 I 1857 udgav Møller pastor M. Mørk Hansens pjece: »Bidrag til Bedømmelsen af Sønderjyllands Sprogforhold ", som indeholdt en omtale af pastor Fr. Petersens »berygtede" bog: »Erlebnisse eines schleswigschen Predigers ${ }^{46}$ Det lille skrift blev købt af Folkeskriftselskabet i 612 eksemplarer og udsendt til medlemmerne uden for skriftrækken. Senere blev Gyldendalske Boghandel hovedkommissionær for selskabet. ${ }^{47}$

"Dannevirke" giver et godt billede af, hvordan bøgerne blev modtaget i samtiden. Fr. Hammerichs skrifter modtoges med stor tilfredshed, kun mente bladet, at der var for langt mellem hæfterne, hvorved »læsernes opmærksomhed svækkes «, ${ }^{40}$ men ogsà de andre bøger modtoges gennemgående med stor velvilje, navnlig galder det de historiske, som var i overtal. Om det forste hæf te med blandinger (nr. 4) hed det ganske vist, at skrifter med særskilte emner, hver med sin særskilte titel, lettere skaffede sig indgang, navnlig hos publikum uden for selskabet, men selv om der kunne være fare for smiskmask", mente anmelderen dog, at Folkeskriftselskabet denne gang som tidligere heldigt havde undgået den fare sunder det folkeliges firma at bringe trivialiteter til torvs, og den ros er ikke ringe ${ }^{4}{ }^{48}$

Skriftrækkens andet bind, pastor Boisens bog om danske folke- 
sagn, var fremkommet efter opfordring fra "Dannevirke", idet bogens indhold var kendt fra Boisens foredrag $\mathrm{i}$ "Harmonien ${ }^{48}$ og kritikken var yderst venlig. Bøgerne blev dog af og til modtaget med ret stærk kritik, selv bindet om Sundeved, idet anmelderen ikke fandt behag $i$ de fleste af de anførte sagn, „der synes at stå ammestuehistorierne nærmere end de egentlige folkesagn". ${ }^{50}$ Det var dog navnlig C. Fibigers bog om lyset (nr. 33), som blev udsat for hård omtale. ${ }^{51}$ Anmelderen mente, at det var ,et fuldstændigt fejlgreb af selskabets bestyrelse at udgive et sådant skrift", og at ikke alle bestyrelsesmedlemmer kunne have set og godkendt manuskriptet, og bladet mente, at der burde være et repræsentantskab eller en kontrolkomite ved siden af bestyrelsen, som kunne sige nej til en udsendelse. Det fra det norske selskab overtagne skrift om Skandinavien omtales som et planløst arbejde, hvis behandling var "noget løs og pulterkammermæssig“. ${ }^{52}$

Ved selskabets tiårige jubilæum i 1862 fremkom en sammenfattende bedømmelse af dets virke, ${ }^{53}$ det hedder her bl. a.: „Dersom det var nødvendigt at dokumentere, hvor stor trangen til dansk læsning er i vor provins, kunne der ikke let anføres et pålideligere vidnesbyrd end den virksomhed, som dette selskab nu har udfoldet $i$ en række af år på en naturlig måde, uden kunstige midler, og som stiller det i række med lignende selskaber, som have haft endog hovedstadens rige midler til rådighed, f. eks. Trykkefrihedsselskabet. I henseende til skrifternes indhold tør det påstås, at Folkeskriftselskabet har løst sin opgave vel og — måske med undtagelse af enkelte strengt naturvidenskabelige skrifter vidst at byde et stof, som kunne tiltale alle dets medlemmer trods deres forskellige standpunkt".

Det er ikke meningen at give en vurdering af de udsendte skrifter, men der kan være grund til at fremhæve selskabets stærke tilknytning til hertugdømmet Slesvig. En lang række af skrifterne kunne være placeret $i$ en sønderjysk historisk årbog.

Hæfterne er ret sjældne, $i$ alt fald for enkeltes vedkommende. Det har endog ikke været muligt at finde frem til nr. 45, der må være udkommet $i$ slutningen af 1863 , men om hvilket vi ikke ved nærmere, kun kender vi nr. 44 og 46, og der må derfor have været et mellemliggende bind. ${ }^{54}$

Folkeskriftselskabet er blevet betragtet som en efterfølger af 
Trykkefrihedsselskabet, ${ }^{85}$ og Marckmann, der var et meget energisk medlem af dette selskab og senere stifter af Haderslev-selskabet, må berettige hertil. Man har også villet lade det fortsætte af det af Den Danske Folkeforening nedsatte Udvalg for Folkeoplysningens Fremme, ${ }^{56}$ idet vi blandt dette udvalgs første medlemmer møder pastor $H$. V. Rasmussen ${ }^{57}$ og blandt dets skrifter finder Chr. Dorphs »Kongespejlet" $i$ en anden udgave $1892 \mathrm{og}$ blandt forfattere, som har bidraget til udvalgets skrifter, som flittige bidragydere foruden pastor Rasmussen af Haderslev-selskabets bestyrelse møder Chr. Grønlund og S. B. Thrige.58

Det blev kun et kort åremål, Folkeskriftselskabet fik lov til at virke, som for alt andet dansk arbejde i Sønderjylland satte krigen i 1864 en brat stopper, men de mænd, som fik ideen til selskabet og fik det dannet, og som trods store vanskeligheder fik arbejdet til at gå og gennemførte den kraftpræstation, det må have været at udsende de 46 hæfter, fortjener tak for den indsats, de her har ydet. Det var et arbejde af betydning for hele landet, men først og fremmest for den landsdel, som de havde ønsket at hellige deres arbejde. 


\section{Tillæg.}

Fortegnelse over Danske Folkeskrifter udgivet af Folkeskriftselskabet i Haderslev.

I Den slesvigske Treaarskrig. Af Fr. Hammerich. Haderslev 1852, 161 sider.

II To Fortællinger, oversatte efter Charles Dickens' "Household-Words «. Haderslev 1853, 129 sider.

III Nordiske Gudesagn, fortalte og anvendte af F. E. Boisen. Haderslev 1853, 133 sider.

IV Blandinger. Forste Hæfte. Haderslev 1853, 144 sider. (Indhold: Knud Eriksen Lavard. Af Richelieu, Præst i Løit, s. 1. Gummi elasticum og Gutta percha. Af Grønlund, Lærer ved Haderslev lærde Skole, s. 34. Vandringer i Syrien og det hellige Land. Meddeelt af Mag. L. N. Boisen, s. 40. Om Havets Bevægelser. Af Møller, Præst i Vonsbæk, s. 111).

$V$ Et Forsøg paa en almeenfattelig Fremstilling af Chemiens vigtigste Resultater. Ved Julius Thomsen. Haderslev (Kjøbenhavn) 1853, 149 sider, ill.

VI Danmark under Kongerne af den ældre oldenborgske Linie. (1448-1523). Af Fr. Hammerich. Haderslev (Kjøbenhavn) 1854,218 sider.

VII Blandinger. Andet Hæfte. Haderslev 1854, 114 sider. (Indhold: Om Staden Ninive, som blev begravet og staaer op igjen. Af J. V. Marckmann, s. 1. Nordfriserne og Nordstrands Undergang 1634. Af Richelieu, s. 30. Om hellige Steder i Sønderjylland i Hedenold. Af J. Fibiger, s. 80).

VIII Danmark under Adelsvælden (1523-1660). Af Fr. Hammerich. 1ste Binds 1ste Hæfte. Haderslev (Kjøbenhavn) 1854, side 1-118.

IX Almeenfattelig Veirlære. Ved P. Pedersen. Med Træsnit og 2 Kort. Haderslev (Kjøbenhavn) 1854, 156 sider.

$\mathrm{X}$ Vandringer i Syrien og det hellige Land. Meddeelt af L. N. Boisen. Haderslev 1854, 103 sider. 
XI = VIII 1ste Binds 2det Hrfte. Haderslev (Kjøbenhavn) 1855 , side 119-228.

XII = VIII 2det Binds 1ste Hæfte. Haderslev (Kjøbenhavn) 1855, side 1-92.

XIII = VIII 2det Binds 2det Hafte. Haderslev (K jøbenhavn) 1855, side 93-192.

XIV Skildringer og Sagn fra Færøerne. Af P. A. Holm, Adjunct. Haderslev (Kjøbenhavn) 1856, 124 sider.

$\mathrm{XV}=$ VIII 3die Binds 1ste Hrfte. Haderslev (Kjøbenhavn) 1856 , side 1-66.

XVI $=$ VIII 3die Binds 2det Hafte. Haderslev (Kjøbenhavn) 1856, side 67-136.

XVII $=$ VIII 3die Binds 3die Hæfte. Haderslev (Kjøbenhavn) 1856, side 137-222.

XVIII Planternes Bygning og Liv. Almeenfattelig fremstillet af C. Gronlund. Haderslev 1857, 144 sider, ill.

XIX Fortsatte Vandringer i Syrien og det hellige Land. Ved L. N. Boisen. Haderslev 1857, 112 sider.

XX Christelige Erindringer fra Rom. Af J. P. C. Scharling. Cand. theol. Haderslev 1857, 132 sider.

XXI Hvorledes England blev erobret og bebygget af de Danske og siden har baaret Mærker deraf. Af J. W. Marckmann. Haderslev 1857, 120 sider.

XXII Den sidste europæiske Krig. Af H. Lassen. Efter det norske Tidsskrift »Folkevennen" paany udgivet af Folkeskriftselskabet i Haderslev. Haderslev 1858, 135 sider.

XXIII Hundrede og tyve af Holbergs Epistler. Udgivne til Almeen Læsning ved F. Fabricius. [Haderslev] Kjøbenhavn 1858,417 sider.

XXIV Præsident Hans Nansen den Eldres Levnet. Ved Fr. Hammerich. Haderslev 1858, 39 sider.

XXV Stedmoderen. En Fortælling af Auerbach. Oversat af Forf. til Clara Raphaels Breve. Haderslev 1858, 125 sider.

XXVI $=$ VIII 4de Binds 1ste Hæfte. Haderslev (Kjøbenhavn) 1858, side 1-120. 
XXVII Gamle og nye Minder fra Sundeved. Af Chr. C. Lorenzen, Adjunkt ved Domskolen i Slesvig. Haderslev 1859, 82 sider.

XXVIII Danskhedens Skjæbne i Slesvig, udarbejdet efter Prof. Allens Værk "Det danske Sprogs Historie i Hertugdømmet Slesvig eller Sønderjylland " ved J. W. Marckmann. Haderslev 1859, side 1-96.

XXIX = VIII 4die Binds 2det Hæfte. Haderslev (Kjøbenhavn) 1859, side 121-240.

XXX Skandinaviens Beskrivelse. Af Ludv. Daa. Første Afdeling. Udgivet af det norske Selskab for Folkeoplysningens Fremme. Kristiania 1859. [På omslaget: Haderslev (Kristiania) 1860], 296 sider.

XXXI $=$ XXVIII Haderslev 1860, side I-XII og 97-231.

XXXII $=$ VIII 4de Binds 3die Hæfte. Haderslev (Kjøbenhavn) 1860, side 241-372.

XXXIII Lyset og dets Egenskaber. Letfattelig Fremstilling i tre Foredrag af C. Fibiger. Med 95 Træsnit. Haderslev (Kjøbenhavn) 1860, 110 sider.

XXXIV Grønland skildret af V. Vallø. Haderslev 1861, 125 sider.

XXXV Blandinger. Haderslev 1861, 94 sider. (Indhold: Nis Lorentsen fra Lilholt, skildret af H. V. Rasmussen, side 1. Erindringer fra Krigsaarene 1849 og 1850 , s. 39. Burtons Besøg i Mekka, s. 77).

XXXVI Forverdenens Planter og Dyr. Af Chr. Grønlund. Med 50 Træsnit. Haderslev 1861, 142 sider.

XXXVII Krigen i Norditalien 1859 ved Carl Sørensen, Lieutenant. Haderslev 1861, 147 sider.

XXXVIII Harald Haardraades Saga. Paany fortalt af S. B. Thrige. Haderslev 1862, 105 sider.

XXXIX Kongespejlet i Uddrag. Oversat af Chr. Dorph. Haderslev 1862,117 sider.

XL Krigen i Syditalien 1860. Ved Carl Sørensen, Lieutenant. Haderslev 1862, 157 sider. 
XLI Blodvidnerne $\mathrm{i}$ den christelige Kirkes tre første Aarhundreder. Af $H$. V. Rasmussen, Haderslev 1862, 157 sider.

XLII Australiens Opdyrkning. Efter Hubert de Castella: Les Squatters Australiens. Ved J. Magnussen. Haderslev 1863,203 sider.

XLIII Dannevirke og Omegn. Af Chr. C. Lorenzen, Præst i Siversted. Haderslev 1863, 89 sider.

XLIV Blandinger. Ny Samling. Haderslev 1863, 105 sider. (Indhold: Hravnkel Freysgodes Saga. Gjenfortalt af H. H. Lefolii, s. 1. Lidt om Dyrkning af Potteplanter. Af C. Gronlund, s. 41. En Udflugt til Sicilien. Af J. P. C. Scharling, s. 65).

XLV Skriftet er helt ukendt.

XLVI Fra Heden. Af H. F. Feilberg, Sognepræst i Store Vi ved Flensborg. Haderslev 1863 [på titelbladet, på omslaget 1864], 155 sider.

\section{NOTER OG HENVISNINGER}

1. Lauridsen SJy vågnede, s. 104 .

2. Festskrift til H. P. Hanssen, 1932, s. 188 (Jakob Petersen).

3. Harmonien. Haderslev 1949, s. $111 \mathrm{ff}$.

4. Had Samf 1934, s. 16. (Edvard Lembcke).

5. Had Samf 1945, s. 11. (Torben Glahn).

6. Had Samf 1935, s. 36 og $42 \mathrm{ff}$.

7. Had Samf 1934, s. 18.

8. Harmonien. Haderslev 1949, s. $102 \mathrm{f}$.

9. Dv 6/9 1854 .

10. Olav Christensen: Haderslev bys forste bogtrykker Hinrich Luckander. Haderslev 1959.

11. Arthur Christensen: Molboernes vise gerninger. 1939, s. $61 \mathrm{ff}$.

12. SJy Årb 1889, s. 290 f.

13. Dv 6/11 1854 .

14. J. Aarsbo: Bibliotekerne og Samfundet. 1935, s. 19.

15. Dv $8 / 7$ og $23 / 71852$.

16. Danske Folkeskrifter (i det følgende D F ) nr. 1, omslagets bagside.

17. Dv 23/12 1852 .

18. D F nr. 1, jfr. Dv 23/12 1852 .

19. D F nr. 8, tillæg.

20. Trykkefrihedsselskabet havde, da medlemstallet kulminerede, over 5000 medlemmer, men tallet var i 1848 faldet til 2100. Dansk Folkeblad $1838 / 39$, s. 30 , og 1848 , s. 14 .

21. D F nr. 13, tillæg. 
22. D F nr. 27, tillæg.

23. I) F nr. 36, tillæg.

24. Dv $23 / 111861$.

25. D F nr. 13, 27 og 36, tillæg.

26. Dv $29 / 21856$.

27. D F nr. 8, 13 og 27, tillæg.

28. D F nr. 36, tillæg.

29. Dv 29/12 1862 .

30. Dv $24 / 121860$.

31. Dv $14 / 21854$.

32. D F nr. 13, 27 og 36, jfr. Dv 14/6 1860 .

33. Gyldendalske Boghandels arkiv i Det Kgl. Bibliotek. Jeg skylder forlaget tak for denne oplysning.

34. D F nr. 27, tillæg.

35. Ehrencr.-M Forf Lex bd X, s. 428-31, indeholder intet om, at epistlerne er udsendt i selskabets omslag, ligesom bogen i denne skikkelse forgæves er eftersagt i Holberg-samlingerne i Kristiansands Folkebibliotek, i Bergen offentlige Bibliotek og i Deichmanske Bibliotek i Oslo samt i Universitetsbiblioteket i Oslo. Jeg skylder de fire biblioteker tak herfor.

36. Arkiver og samlinger efter private nr. 78 i Riksarkivet i Oslo, som venligst har meddelt mig udskrifter af Selskabet for Folkeoplysningens Fremmes forhandlingsprotokol.

37. Dv $14 / 11858$.

38. Dv 14/1 1858, D F nr. 22, forordet og omslagets bagside.

39. D F nr. 40, omslagets bagside.

40. Dv $14 / 61860$.

41. Had Samf 1935, s. 37 .

42. Dv $20 / 81861$.

43. D F nr. 36, jfr. Slesv Prov Eft bd 2, s. 401.

44. Dv $30 / 121852$ og $19 / 31853$.

45. Johs. Chr. Nielsen: 165 år. Haderslev 1931.

46. D F nr. 27, jfr. Dv 12/5 1857.

47. Dv $9 / 51862$.

48. Dv $26 / 10$ og $28 / 101853$.

49. Dv $5 / 31852$.

50. Dv $9 / 71859$.

51. Dv 22/12 1860 .

52. Dv $20 / 61860$.

53. Dv $18 / 101862$.

54. Hæfte 44 er anmeldt i Dv 29/9 1863, senere er Folkeskriftselskabet ikke omtalt. Landsbiblioteket i Ảbenrå har den største samling af folkeskrifterne, men også her savnes nr. 45.

55. J. Aarsbo: Bibliotekerne og Samfundet. 1935, s. 34.

56. P. Bojsen: Budstikkens udgiver, præsten F. E. Bojsens liv og levned. 1883, s. 212.

57. Udvalget for Folkeoplysningens Fremme 1866-1916. 1916, s. XLIV.

58. S. st. s. 32, 123,133 og 138. 